\title{
Exogenous application of growth stimulators improves the condition of maize exposed to soil drought
}

\author{
Agnieszka Ostrowska ${ }^{1}$ (D) Maciej T. Grzesiak ${ }^{1} \cdot$ Tomasz Hura $^{1}$
}

Received: 9 January 2020 / Revised: 23 February 2021 / Accepted: 15 March 2021 / Published online: 20 March 2021

(c) The Author(s) 2021

\begin{abstract}
Soil drought is a major problem in plant cultivation. This is particularly true for thermophilic plants, such as maize, which grow in areas often affected by precipitation shortage. The problem may be alleviated using plant growth and development stimulators. Therefore, the aim of the study was to analyze the effects of 5-aminolevulinic acid (5-ALA), zearalenone (ZEN), triacontanol (TRIA) and silicon ( $\mathrm{Si}$ ) on water management and photosynthetic activity of maize under soil drought. The experiments covered three developmental stages: three leaves, stem elongation and heading. The impact of these substances applied during drought stress depended on the plant development stage. 5-ALA affected chlorophyll levels, gas exchange and photochemical activity of PSII. Similar effects were observed for ZEN, which additionally induced stem elongation and limited dehydration. Beneficial effects of TRIA were visible at the stage of three leaves and involved leaf hydration and plant growth. A silicon preparation applied at the same developmental stage triggered similar effects and additionally induced changes in chlorophyll levels. All the stimulators significantly affected transpiration intensity at the heading stage.
\end{abstract}

Keywords Water stress $\cdot 5$-aminolevulinic acid $\cdot$ Triacontanol $\cdot$ Silicon $\cdot$ Zearalenone

$\begin{array}{ll}\text { Abbreviations } \\ \text { ABS/CS } & \text { Amount of light energy absorption } \\ \text { 5-ALA } & \text { 5-Aminolevulinic acid } \\ \text { Chl. } & \text { Chlorophyll content } \\ \mathrm{C}_{\mathrm{i}} & \text { Intercellular concentration of } \mathrm{CO}_{2} \\ \mathrm{CS}_{\mathrm{m}} & \text { Leaf cross section } \\ \mathrm{DI}_{0} / \mathrm{CS}_{\mathrm{m}} & \text { Energy amount dissipated from PSII } \\ \mathrm{DW}_{\mathrm{E}} & \text { Dry weight } \\ \mathrm{E} & \text { Transpiration } \\ \mathrm{ET}_{0} / \mathrm{CS}_{\mathrm{m}} & \text { Amount of energy used for electron transport } \\ \mathrm{F}_{\mathrm{v}} / \mathrm{F}_{\mathrm{m}} & \text { Quantum yield of PSII } \\ \mathrm{FW} & \text { Fresh weight } \\ \mathrm{gs} & \text { Stomatal conductance } \\ \mathrm{Kr} & \text { Water hydraulic conductance } \\ \mathrm{PAR} & \text { Photosynthetically active radiation } \\ \mathrm{PI} & \text { Overall performance index of PSII } \\ & \text { photochemistry }\end{array}$

Communicated by O. Ferrarese-Filho.

Agnieszka Ostrowska

a.ostrowska@ifr-pan.edu.pl

1 Polish Academy of Sciences, The Franciszek Górski Institute of Plant Physiology, Niezapominajek 21, 30-239 Kraków, Poland

$\begin{array}{ll}\mathrm{P}_{\mathrm{N}} & \text { Photosynthetic rate } \\ \text { PPDF } & \text { Photosynthetic photon flux density } \\ \text { PSII } & \text { Photosystem II } \\ \mathrm{Q}_{\mathrm{A}} & \text { Plastoquinone A } \\ \mathrm{Q}_{\mathrm{B}} & \text { Plastoquinone B } \\ \text { RC/CS } & \text { Number of active reaction centers } \\ \text { RWC } & \text { Relative water content } \\ \mathrm{Si} & \text { Silicon } \\ \text { TRIA } & \text { Triacontanol } \\ \text { TR0/CSm } & \text { Amount of excitation energy trapped in PSII } \\ & \text { reaction centers } \\ \text { TW } & \text { Turgid weight } \\ \text { WUE } & \text { Water use efficiency } \\ \text { ZEN } & \text { Zearalenone } \\ \varphi E_{\mathrm{o}} & \text { Effective quantum yield of electron transport } \\ & \text { flux from the primary quinone acceptor } \mathrm{Q}_{\mathrm{A}} \text { to } \\ \Psi_{\mathrm{o}} & \mathrm{Q}_{\mathrm{B}}\end{array}$

\section{Introduction}

Plant growth and development stimulators play an increasingly important role in global agriculture (Duan et al. 2006; Hajam et al. 2018). Contrary to traditional 
fertilizers, they are used at very low concentrations ( $\mathrm{mg}$ $\mathrm{L}^{-1}$ ), so they do not evoke harmful or permanent environmental changes. Plant growth stimulators include, e.g., aminolevulinic acid (5-ALA), triacantanol (TRIA), zearalenone (ZEN), and silicon (Si). Despite different chemical structure, their common feature is the possibility of limiting negative effects of environmental stresses on crop productivity (Hotta et al. 1997; Korndorfer and Lepsch 2001; Naeem et al. 2009; Biesaga-Kościelniak and Filek 2010).

5-aminolevulinic acid (5-ALA) is an essential precursor of all porphyrin compounds, including chlorophyll and heme (von Wettstein et al. 1995; Wu et al. 2019). Exogenous application of 5-ALA diminishes negative effects of drought (AlKhateeb 2006; Ostrowska et al. 2019), cold (Korkmaz and Korkmaz 2009), shade (Sun et al. 2009), salinity (Nishihara et al. 2003), or heavy metals (Ali et al. 2013). The stimulator affects also chlorophyll content (Xu et al. 2010), gas exchange (Akram et al. 2018), water relations (Korkmaz et al. 2010), and activity of antioxidant enzymes (Balestrasse et al. 2010; Naeem et al. 2011).

Zearalenone (ZEN) is a mycotoxin of strong estrogenic activity produced by fungi of the genus Fusarium (Stob et al. 1962). ZEN activity is similar to that of plant hormones (Biesaga-Kościelniak and Filek 2010; Filek et al. 2010). It influences plant yield, photosynthetic apparatus activity, fatty acid level, phytosterol content, and ion uptake (Biesaga-Kościelniak 2001; Kościelniak et al. 2009). ZEN may also change the intensity of plant respiration and $\mathrm{CO}_{2}$ assimilation (Biesaga-Kościelniak et al. 2003; SzechyńskaHebda et al. 2007; Biesaga-Kościelniak and Filek 2010), as well as permeability of cell membranes to electrolytes (Biesaga-Kościelniak 2001). Its regulatory activity is evidenced by the fact that it can also partly replace the lowtemperature requirement for ear development in winter wheat (Fu and Meng 1994; Fu et al. 2000; Filek et al. 2010). Kościelniak et al. (2011) demonstrated a protective effect of ZEN on PSII photochemical activity and growth in wheat and soybean exposed to salt stress.

Triacontanol (TRIA), a saturated long-chain alcohol, is a natural component of plant epicuticular waxes (Ries et al. 1977; Chen et al. 2002). Exogenous application of TRIA enhances the content of photosynthetic pigments, carbohydrates, amino acids and proteins, increases dry weight and leaf area, and improves membrane integrity (Ries and Stutte 1985; Rajasekaran and Blake 1999; Muthuchelian et al. 2001). Foliar treatment with TRIA increased catalase and peroxidase activity and decreased the contents of $\mathrm{H}_{2} \mathrm{O}_{2}$, malondialdehyde, phenolics and glycinebetaine under stress (Perveen et al. 2016).

TRIA upregulated photosynthesis and suppressed stress in rice (Chen et al. 2002). It also exerted protective effects in plants exposed to heavy metals (Muthuchelian et al. 2001), drought (Rajasekaran and Blake 1999), or salinity (Shahbaz et al. 2013).

Although silicon ( $\mathrm{Si}$ ) is not an essential element in plants, multiple studies confirmed its positive influence on plant growth and development (Ma et al. 2006; Gunes et al. 2007; Balakhnina et al. 2012). Its protective effects during salt stress manifest in enhanced activity of antioxidant enzymes, elevated chlorophyll content and increased photochemical efficiency of PSII (Al-aghabary et al. 2005). Another study on salt stress demonstrated that an addition of silicon could increase net photosynthetic rate and reduce membrane permeability (Liang et al. 1996). Moussa (2006) showed that $\mathrm{Si}$ addition during stress can significantly reduce $\mathrm{H}_{2} \mathrm{O}_{2}$ content, proline level, malondialdehyde concentration, and enhance chlorophyll content and photosynthetic activity. Silicon also improved water status and increased dry mass of wheat plants under drought stress (Gong et al. 2003). Even though silicon is the second most prevalent element in the soil, majority of its sources are insoluble and occur in plant-unavailable form (Balakhnina and Borkowska 2013).

Drought stress is one of the key factors limiting crop productivity. This is a particularly challenging problem for thermophilic plants, such as maize, which are often grown in the areas experiencing precipitation shortage (Campos et al. 2004; Tsonev et al. 2009; Ghahfarokhi et al. 2015). Therefore, the aim of the study was to analyze the effects of 5-ALA, ZEN, TRIA and Si on water management and photosynthetic activity of maize under soil drought. We assumed that the exogenous application of the plant growth stimulators may alleviate the negative effects of leaf dehydration.

\section{Materials and methods}

\section{Plant material and plant growth conditions}

The experiments involved a cultivar 'Kosmo 230' (Małopolska Plant Breeding Station Ltd.) intended for both silage and grain yield. The cultivar is grown in water-rich soils. The experiments were carried out under controlled greenhouse conditions of $16 \mathrm{~h}$ photoperiod, temperature $25 / 20{ }^{\circ} \mathrm{C}$ (day/night) and air humidity $45 \pm 5 \%$. Photosynthetic photon flux density (PPDF) at the level of top leaves was about $290-380 \mu \mathrm{mol} \mathrm{m}^{-2} \mathrm{~s}^{-1}$. These conditions were also continued during drought.

\section{Growth stimulators}

Based on the data found in the literature, we used the following concentrations of the growth stimulators: ZEN $2 \mathrm{mg} \mathrm{dm}^{-3}$, 5-ALA $3 \mathrm{mg} \mathrm{dm}^{-3}$, TRIA $1 \mathrm{mg} \mathrm{dm}^{-3}$. Silicon was applied as a commercial preparation Optysil (Intermag Ltd., Poland) that included the element in the form of 
stabilized silicic acids. A solution was prepared according to the manufacturer's recommendations, in which the concentration of silicon reached $0.5 \mathrm{mg} \mathrm{dm}^{-3}$.

\section{Drought and treatment with growth stimulators}

\section{Experiment 1}

The aim of this experiment was to determine the effect of plant growth stimulators applied at a very early stage of the plant development (three-leaf stage) under soil drought.

The plants were grown separately in pots $(0.1 \mathrm{~L})$ filled with vermiculite and watered once a week with Hoagland medium (Hoagland 1948). Once the plants developed their third leaf, they were divided into six groups: control without spraying $\left(\mathrm{C}_{\mathrm{a}}\right)$, water spraying $\left(\mathrm{C}_{\mathrm{w}}\right)$, ZEN, TRIA, 5-ALA, and silicon preparation $(\mathrm{Si})$. The spraying was performed three times at two-day intervals. After the last spraying, watering was ceased until soil moisture content dropped to $35-40 \%$, and this level was maintained for 7 days. All experimental variants (also control) were subjected to soil drought. After this time, chlorophyll content $(n=15)$, plant height $(n=15)$ and relative water content (RWC) $(n=7)$ were measured. The measurements involved the first (Chl.) and the second (RWC) fully developed leaf from the top of a single plant. One repetition means one plant.

\section{Experiment 2}

The aim of this experiment was to determine the effect of plant growth stimulators applied at stem elongation stage on the plant development under soil drought.

Individual plants were grown in pots $(2 \mathrm{~L})$ filled with a mixture of garden soil and sand $(2: 1, v / v)$, and watered once a week with Hoagland medium (Hoagland 1948). At the beginning of stem elongation stage, the plants were divided into five groups, similarly as in Experiment 1 (except for $\mathrm{C}_{\mathrm{w}}$, no effects of spraying with water vs. $\mathrm{C}_{\mathrm{a}}$ ). Spraying with the preparations occurred three times at two-day intervals. Then, watering was stopped until the soil moisture content dropped to $35-40 \%$, and this level was maintained for 10 days. All groups of plants (also control) were subjected to soil drought. It was controlled by weighing the pots and subtracting the plant weight. Measurements were performed on the 10th day of drought.

After this time, relative water content (RWC) $(n=7)$, osmotic potential ( $\left.\Psi_{0}\right)(n=7)$, chlorophyll content (Chl.) $(n=10)$, intensity of stomatal conductance (gs) $(n=10)$, and water hydraulic conductance $(\mathrm{Kr})(n=7)$ were evaluated. The measurements were performed in the first (Chl., gs, $\Psi_{0}$ ) and the second (RWC) fully developed leaf from the top of a single plant. A single plant (without the stem cut off at a height of $5 \mathrm{~cm}$ ) was used to measure the hydraulic conductivity. One repetition means one plant.

\section{Experiment 3}

The aim of this experiment was to determine the effect of plant growth stimulators applied at heading stage on the plant development under soil drought.

Individual plants were grown in pots $(4 \mathrm{~L})$ filled with a mixture of garden soil and sand $(2: 1, \mathrm{v} / \mathrm{v})$, and watered once a week with Hoagland medium (Hoagland 1948).Once the head emerged, the plants were divided into five variants, as in Experiment 2. The spraying with preparations was performed three times at 2 day intervals. Then, watering was stopped until the soil moisture level was $35-40 \%$, and this level was maintained for 14 days. All groups of plants (also control) were subjected to soil drought. It was controlled by weighing the pots and subtracting the plant weight. Measurements were carried out on 14th day of drought. After this time, gas exchange $(n=7)$ and photosynthetic activity $(n=12)$ were assessed. Both measurements were performed in the first fully developed leaf from the top of a single plant. One repetition means one plant.

\section{Measurements}

The measurements covered three developmental stages of maize, i.e., three leaves, stem elongation and heading. For each developmental stage water relations were analyzed (three-leaf stage: RWC; stem elongation: RWC, osmotic potential, stomatal conductance, root hydraulic conductance; heading: stomatal conductance, water use efficiency), and plant productivity metrics were assessed (three-leaf stage: chlorophyll content, plant growth analysis; stem elongation: chlorophyll content; heading: activity of photosynthetic apparatus, gas exchange).

\section{Gas exchange at the leaf level}

Gas exchange was measured using an infrared gas analyzer LCpro-SD (ADC BioScientific Ltd., UK). The following parameters were measured: Photosynthetic rate $\left(\mathrm{P}_{\mathrm{N}}\right)$, transpiration $(\mathrm{E})$, stomatal conductance $\left(\mathrm{g}_{\mathrm{S}}\right)$ as well as intercellular concentration of $\mathrm{CO}_{2}(\mathrm{Ci})$. WUE was calculated as $\mathrm{P}_{\mathrm{N}} / \mathrm{E}$. In chamber, $\mathrm{CO}_{2}$ concentration was equal to $360 \mu \mathrm{mol} \mathrm{CO}_{2}$ $\mathrm{mol}^{-1}$ air, humidity was as ambient condition, PAR intensity equal to $600 \mu \mathrm{mol}$ photons $\mathrm{m}^{-2} \mathrm{~s}^{-1}$ and temperature $+22{ }^{\circ} \mathrm{C}$ The adaptation of leaves to chamber condition was continued until stable gas exchange rate was observed. After this time, an automatic record of all tested parameters was made. The measurements were carried out between 10:00 a.m. and 12:00 p.m. and involved the first fully expanded leaf (Gadzinowska et al. 2019). 


\section{Stomatal conductance $\left(\mathbf{g}_{\mathrm{s}}\right)$}

A porometer (Sc-1 Porometer; Decagon devices Inc., USA) was used to measure $g_{s}$. The measurements involved the first fully expanded leaves and were carried out between 10:00 a.m. and 12:00 p.m.

\section{Photochemical efficiency}

Photochemical efficiency was measured using a Handy PEA chlorophyll fluorimeter (Hansatech Ltd., Kings Lynn, UK). Measurements were taken after $30 \mathrm{~min}$. of leaf adaptation to darkness. Light intensity reaching the leaf was $3000 \mu \mathrm{mol}$ (quantum) $\mathrm{m}^{-2} \mathrm{~s}^{-1}$ (peak at $650 \mathrm{~nm}$ ). Changes in fluorescence were registered during irradiation between $10 \mu$ s and $1 \mathrm{~s}$. During the first $2 \mathrm{~ms}$, data were gathered every $10 \mu \mathrm{s}$. After this time, the periodicity of measurements dropped automatically. The collected data were analyzed with a JIP test, based on the theory of energy flow in PSII (Srivastava and Strasser 1977; Lazár 1999; Strasser et al. 2000; Appenroth et al. 2001). The following parameters were calculated per $\mathrm{CS}_{\mathrm{m}}: \mathrm{ABS} / \mathrm{CS}_{\mathrm{m}}, \mathrm{TR}_{0} / \mathrm{CS}_{\mathrm{m}}, \mathrm{ET}_{0} / \mathrm{CS}_{\mathrm{m}}, \mathrm{DI}_{0} / \mathrm{CS}_{\mathrm{m}}$ and $\mathrm{RC} /$ $\mathrm{CS}_{\mathrm{m}}$ (Rapacz et al. 2010). Additionally, $\mathrm{F}_{\mathrm{v}} / \mathrm{F}_{\mathrm{m}}, \varphi \mathrm{E}_{\mathrm{o}}$ and PI were determined (Ostrowska et al. 2019). The measurements involved the central part of the first completely expanded leaf.

\section{Chlorophyll content}

Measurements were performed in the first completely developed leaf from the top with a hand-held chlorophyll meter SPAD-502 (Konica-Minolta, Japan).

\section{Relative water content (RWC)}

Measurements involved the second completely expanded leaf from the top. RWC was determined according to formula: $R W C=[(F W-D W) /(T W-D W)] \times 100 \%$, where $F W$ represents fresh weight — determined immediately after cutting the leaf, $T W$ turgid weight-determined after placed leaves for $24 \mathrm{~h}$ in vials containing water, $D W$ represents dry weight - measured after $48 \mathrm{~h}$ drying the leaves at $80^{\circ} \mathrm{C}$ (Barrs and Weatherley 1962).

\section{Leaf osmotic potential $\left(\Psi_{0}\right)$}

Leaf osmotic potential was analyzed with a psychrometer HR 33 T connected with sample chambers C-52 (WESCOR, Inc., Logan, Utah, USA). The filter paper discs ( $\varnothing 5 \mathrm{~mm}$ ) were soaked with cell sap squeezed with a syringe from the collected leaves. Then, the disk was placed in the measuring chamber and left for $30 \mathrm{~min}$. After that the measurements were taken in the dew point mode (Hura et al. 2012, 2017).

\section{Root hydraulic conductance $\left(\mathrm{K}_{\mathrm{r}}\right)$}

$\mathrm{K}_{\mathrm{r}}$ was estimated using a High-Pressure Flow Meter (Dynamax Inc., USA) as described by Tyree et al. (1995). Entire intact roots were connected to the meter through the shoot excised $5 \mathrm{~cm}$ above the root collar and water was perfused into the root system opposite to the normal direction of flow during transpiration. The root systems were pressurized to $0.15 \mathrm{MPa}$. The perfusion pressure changed at a constant rate of 3-7 $\mathrm{kPa} \mathrm{s}^{-1}$, while measuring the flow into the root every $2-4 \mathrm{~s}$.

\section{Statistical analysis}

Duncan's multiple range test at $p=0.05$ was performed to determine the significance of differences between treatments. All data were analyzed using Statistica 10.0 software (Statsoft Inc., USA).

\section{Results}

The applied substances improved the condition of plants exposed to soil drought at all investigated developmental stages.

The effects of silicon preparation were the most perceptible at the three-leaf stage. The plants treated with silicon demonstrated higher hydration level and chlorophyll content vs. control. We also noted positive effects of the element on plant growth (Table 1).

Treatment with TRIA and ZEN resulted in significant increase in RWC as compared with both control variants $\left(C_{a}\right.$, $\mathrm{C}_{\mathrm{w}}$ ) (Table 1). Better hydration of plants treated with TRIA was associated with significant increase in plant height. The positive effects of 5-ALA were expressed by enhanced chlorophyll content in maize leaves, but the stimulator did not affect leaf water content or elongation growth (Table 1).

Treatment with 5-ALA at the stem elongation stage during soil drought increased chlorophyll content (Table 2). At this developmental stage, we also observed a significant

Table 1 Effects of the investigated stimulators on leaf relative water content (RWC), chlorophyll content (Chl.), and plant height at threeleaf stage stage (Exp.1)

\begin{tabular}{llll}
\hline $\begin{array}{l}\text { Type of spraying } \\
\text { before drought }\end{array}$ & $\begin{array}{l}\text { RWC } \\
{[\%]}\end{array}$ & $\begin{array}{l}\text { Chl } \\
{[\mathrm{c} . \mathrm{u} .]}\end{array}$ & $\begin{array}{l}\text { Plant height } \\
{[\mathrm{cm}]}\end{array}$ \\
\hline $\mathrm{C}_{\mathrm{a}}$ & $83.4 \mathrm{~b}$ & $34.6 \mathrm{~b}$ & $21.9 \mathrm{~b}$ \\
$\mathrm{C}_{\mathrm{w}}$ & $82.2 \mathrm{~b}$ & $33.8 \mathrm{~b}$ & $22.4 \mathrm{~b}$ \\
5-ALA & $85.0 \mathrm{ab}$ & $39.1 \mathrm{a}$ & $23.0 \mathrm{ab}$ \\
TRIA & $87.6 \mathrm{a}$ & $35.5 \mathrm{ab}$ & $25.6 \mathrm{a}$ \\
ZEN & $86.5 \mathrm{a}$ & $37.2 \mathrm{ab}$ & $23.4 \mathrm{ab}$ \\
Silicon & $87.4 \mathrm{a}$ & $38.8 \mathrm{a}$ & $25.9 \mathrm{a}$ \\
\hline
\end{tabular}


Table 2 Effects of the investigated stimulators on relative water content (RWC) $(n=7)$, osmotic potential $\left(\Psi_{0}\right)(n=7)$, chlorophyll content (Chl.) $(n=10)$, intensity of stomatal conductance (gs) $(n=10)$,

\begin{tabular}{|c|c|c|c|c|c|}
\hline $\begin{array}{l}\text { Type of spraying before } \\
\text { drought }\end{array}$ & $\begin{array}{l}\text { RWC } \\
{[\%]}\end{array}$ & $\begin{array}{l}\Psi \mathrm{o} \\
{[\mathrm{MPa}]}\end{array}$ & $\begin{array}{l}\text { Chl } \\
\text { [c.u.] }\end{array}$ & $\begin{array}{l}\text { gs } \\
{\left[\mathrm{mmol}\left(\mathrm{CO}_{2}\right) \mathrm{m}^{-2} \mathrm{~s}^{-1}\right]}\end{array}$ & $\begin{array}{l}\mathrm{K}_{\mathrm{r}} \\
{\left[\mathrm{kg} \mathrm{s}^{-1} \mathrm{MPa}^{-1}\right]}\end{array}$ \\
\hline $\mathrm{C}_{\mathrm{a}}$ & $72.8 \mathrm{~b}$ & $-2.34 \mathrm{~b}$ & $41.4 \mathrm{~b}$ & $67.21 \mathrm{~b}$ & $8.53 \cdot 10^{-6} \mathrm{a}$ \\
\hline 5-ALA & $75.0 \mathrm{ab}$ & $-1.95 a b$ & $48.3 \mathrm{a}$ & $70.82 \mathrm{ab}$ & $8.86 \cdot 10^{-6} \mathrm{a}$ \\
\hline TRIA & $74.0 \mathrm{ab}$ & $-2.54 \mathrm{~b}$ & $40.7 \mathrm{~b}$ & $64.05 \mathrm{~b}$ & $9.23 \cdot 10^{-6} \mathrm{a}$ \\
\hline ZEN & $76.8 \mathrm{a}$ & $-1.56 \mathrm{a}$ & $45.3 \mathrm{ab}$ & 92.69 a & $6.86 \cdot 10^{-6} \mathrm{a}$ \\
\hline Silicon & $76.4 \mathrm{a}$ & $-1.76 \mathrm{a}$ & $43.9 \mathrm{ab}$ & $85.97 \mathrm{a}$ & $7.97 \cdot 10^{-6} \mathrm{a}$ \\
\hline
\end{tabular}

Table 3 Effects of the investigated stimulators on photosynthetic rate $\left(\mathrm{P}_{\mathrm{N}}\right)$, transpiration $(\mathrm{E})$, stomatal conductance $(\mathrm{gs})$, intercellular concentration of $\mathrm{CO}_{2}(\mathrm{Ci})$ and water use efficiency index (WUE) in maize at the heading stage $(n=7)($ Exp.3)

\begin{tabular}{llllll}
\hline $\begin{array}{l}\text { Type of spraying } \\
\text { before drought }\end{array}$ & $\mathrm{P}_{\mathrm{N}}$ & $\mathrm{E}$ & $\mathrm{gs}$ & $\mathrm{Ci}$ & WUE \\
\hline $\mathrm{C}_{\mathrm{a}}$ & $17.4 \mathrm{~b}$ & $1.86 \mathrm{c}$ & $84.2 \mathrm{~b}$ & $128.4 \mathrm{ab}$ & $9.35 \mathrm{a}$ \\
5-ALA & $20.1 \mathrm{a}$ & $3.01 \mathrm{a}$ & $93.6 \mathrm{a}$ & $137.3 \mathrm{a}$ & $6.68 \mathrm{~b}$ \\
TRIA & $18.0 \mathrm{ab}$ & $2.75 \mathrm{~b}$ & $79.4 \mathrm{~b}$ & $119.6 \mathrm{~b}$ & $6.55 \mathrm{~b}$ \\
ZEN & $19.7 \mathrm{a}$ & $2.46 \mathrm{~b}$ & $92.1 \mathrm{a}$ & $118.4 \mathrm{~b}$ & $8.01 \mathrm{a}$ \\
Silicon & $18.6 \mathrm{ab}$ & $2.95 \mathrm{ab}$ & $80.9 \mathrm{~b}$ & $123.0 \mathrm{ab}$ & $6.31 \mathrm{~b}$
\end{tabular}

$\mathrm{P}_{\mathrm{N}}$ : [ $\mathrm{mmol}\left(\mathrm{CO}_{2}\right) \mathrm{m}^{-2} \mathrm{~s}^{-1}$ ]. E: [mmol $\left(\mathrm{H}_{2} \mathrm{O}\right) \mathrm{m}^{-2} \mathrm{~s}^{-1}$ ]. gs: [mmol $\left(\mathrm{H}_{2} \mathrm{O}\right) \mathrm{m}^{-2} \mathrm{~s}^{-1}$ ]. Ci: [ $\mu \mathrm{mol}\left(\mathrm{CO}_{2}\right) \mathrm{mol}(\text { air })^{-1}$ ]. WUE: [ $\mu \mathrm{mol}\left(\mathrm{CO}_{2}\right)$ $\left.\mathrm{mmol}\left(\mathrm{H}_{2} \mathrm{O}\right)\right]$

increase of leaf water content due to ZEN and Si application. In both cases, this was accompanied by considerable growth of the osmotic potential and stomatal conductance in relation to the control. TRIA treatment did not significantly affect the investigated parameters. Similarly, root hydraulic conductance remained unaffected by any of the growth stimulators (Table 2).

At maize heading stage, 5-ALA improved gas exchange parameters and photochemical activity of PSII (Table 3, Table 4). As compared with control, 5-ALA significantly enhanced net photosynthesis rate, transpiration and stomatal and water hydraulic conductance $\left(\mathrm{K}_{\mathrm{r}}\right)(n=7)$ in maize roots during and water hydraulic conductance $\left(\mathrm{K}_{\mathrm{r}}\right)(n=7)$ in maize $\mathrm{root}$

conductance. At the same time, a clear reduction in water use efficiency (WUE) occurred (Table 3). The plants treated with 5-ALA showed higher activity of the photosynthetic apparatus manifested in increased values of Fv/Fm (quantum yield of PSII), PI (overall performance index of PSII photochemistry), ABS/CS $\mathrm{m}_{\mathrm{m}}$ (light energy absorption), $\mathrm{TR}_{\mathrm{o}} / \mathrm{CS}_{\mathrm{m}}$ (amount of excitation energy trapped in PSII reaction centers) and $\mathrm{ET}_{\mathrm{o}} / \mathrm{CS}_{\mathrm{m}}$ (amount of energy used for electron transport). This stimulator did not alter $\mathrm{DI}_{\mathrm{o}} / \mathrm{CS}_{\mathrm{m}}$ value (energy amount dissipated from PSII) (Table 4).

ZEN application at the heading stage significantly improved net photosynthesis rate, transpiration and stomatal conductance. Intercellular concentration of $\mathrm{CO}_{2}(\mathrm{Ci})$ and WUE remained unaffected (Table 3 ). The presence of this stimulator during soil drought significantly influenced PSII activity. We noted a boost in quantum yield of PSII, overall performance index of PSII photochemistry and the amount of energy used for electron transport, while $\mathrm{ABS} / \mathrm{CS}_{\mathrm{m}}$ and $\mathrm{TR}_{\mathrm{o}} / \mathrm{CS}_{\mathrm{m}}$ remained unaltered.

At the heading stage occurring during soil drought TRIA influence on gas exchange was less perceptible and manifested in significant increase of transpiration intensity as compared with control. The influence was accompanied by reduced water use efficiency (WUE) (Table 3). Treatment with TRIA significantly enhanced light energy absorption $\left(\mathrm{ABS} / \mathrm{CS}_{\mathrm{m}}\right)$ and the amount of energy used for electron transport $\left(\mathrm{ET}_{\mathrm{o}} / \mathrm{CS}_{\mathrm{m}}\right)$ together with $\mathrm{DI}_{\mathrm{o}} / \mathrm{CS}_{\mathrm{m}}$ value (Table 4).
Table 4 Effects of the investigated stimulators on quantum yield of PSII $\left(F_{v} / F_{m}\right)$, effective quantum yield of electron transport flux from the primary quinone acceptor $\mathrm{Q}_{\mathrm{A}}$ to $\mathrm{Q}_{\mathrm{B}}(\varphi \mathrm{Eo})$ and overall performance index of PSII photochemistry (PI) and also parameters of JIP test: light energy absorption ( $\left.\mathrm{ABS} / \mathrm{CS}_{\mathrm{m}}\right)$, amount of excitation energy trapped in PSII reaction centers $\left(\mathrm{TR}_{0} / \mathrm{CS}_{\mathrm{m}}\right)$, amount of energy used for electron transport $\left(\mathrm{ET}_{0} / \mathrm{CS}_{\mathrm{m}}\right)$, energy amount dissipated from PSII $\left(\mathrm{DI}_{0} / \mathrm{CS}_{\mathrm{m}}\right)$ and number of active reaction centers $\left(\mathrm{RC} / \mathrm{CS}_{\mathrm{m}}\right)$ per excited leaf cross-section $\left(\mathrm{CS}_{\mathrm{m}}\right)$ in maize at the heading stage $(n=12)$ (Exp.3)

\begin{tabular}{lllllllll}
\hline $\begin{array}{l}\text { Type of spraying } \\
\text { before drought }\end{array}$ & $\mathrm{F}_{\mathrm{v}} / \mathrm{F}_{\mathrm{m}}$ & $\varphi \mathrm{Eo}$ & $\mathrm{PI}$ & $\mathrm{ABS} / \mathrm{CS}_{\mathrm{m}}$ & $\mathrm{TR}_{0} / \mathrm{CS}_{\mathrm{m}}$ & $\mathrm{ET}_{0} / \mathrm{CS}_{\mathrm{m}}$ & $\mathrm{DI}_{0} / \mathrm{CSm}$ & $\mathrm{RC}_{\mathrm{CS}}$ \\
\hline $\mathrm{C}_{\mathrm{a}}$ & $0.701 \mathrm{~b}$ & $0.34 \mathrm{a}$ & $0.85 \mathrm{c}$ & $2023.6 \mathrm{c}$ & $1374.1 \mathrm{~b}$ & $694.3 \mathrm{c}$ & $649.5 \mathrm{~b}$ & $628.4 \mathrm{a}$ \\
5-ALA & $0.758 \mathrm{a}$ & $0.33 \mathrm{a}$ & $0.96 \mathrm{a}$ & $2253.4 \mathrm{a}$ & $1567.7 \mathrm{a}$ & $743.8 \mathrm{a}$ & $685.7 \mathrm{~b}$ & $662.8 \mathrm{a}$ \\
TRIA & $0.714 \mathrm{~b}$ & $0.34 \mathrm{a}$ & $0.87 \mathrm{bc}$ & $2174.0 \mathrm{~b}$ & $1415.2 \mathrm{ab}$ & $737.9 \mathrm{ab}$ & $758.8 \mathrm{a}$ & $647.3 \mathrm{a}$ \\
ZEN & $0.762 \mathrm{a}$ & $0.36 \mathrm{a}$ & $0.91 \mathrm{ab}$ & $2049.2 \mathrm{c}$ & $1410.0 \mathrm{ab}$ & $729.1 \mathrm{ab}$ & $639.2 \mathrm{~b}$ & $627.9 \mathrm{a}$ \\
Silicon & $0.737 \mathrm{ab}$ & $0.35 \mathrm{a}$ & $0.89 \mathrm{bc}$ & $2075.4 \mathrm{c}$ & $1354.1 \mathrm{~b}$ & $717.4 \mathrm{bc}$ & $721.3 \mathrm{a}$ & $690.8 \mathrm{a}$ \\
\hline
\end{tabular}


Silicon preparation applied at the heading stage intensified transpiration and reduced WUE (Table 3 ). Its effects on the photosynthetic apparatus included a significant increase in the amount of energy dissipated from PSII (DI $/ \mathrm{CS}_{\mathrm{m}}$ ) (Table 4).

None of the experimental growth stimulators triggered changes in the number of active reaction centers $\left(\mathrm{RC} / \mathrm{CS}_{\mathrm{m}}\right)$, effective quantum yield of electron transport flux from the primary quinone acceptor $\mathrm{Q}_{\mathrm{A}}$ to $\mathrm{Q}_{\mathrm{B}}\left(\varphi \mathrm{E}_{\mathrm{o}}\right)$ or intercellular concentration of $\mathrm{CO}_{2}(\mathrm{Ci})$ (Tables 3,4$)$. The parameter most sensitive to their application was transpiration intensity (Table 3), and among chlorophyll fluorescence parameters the one associated with the amount of energy used for electron transport $\left(\mathrm{ET}_{\mathrm{o}} / \mathrm{CS}_{\mathrm{m}}\right)$ (Table 4$)$.

\section{Discussion}

Our experiments showed a modification of maize response to soil drought triggered by the application of plant growth stimulators. All the investigated substances affected water relations and photosynthetic activity with different intensity and distinctive effects.

5-ALA influenced mainly gas exchange and photochemical activity of PSII (Tables 3, 4). A similar response of the photosynthetic apparatus to 5-ALA was reported for salinity stress (Naeem et al. 2011) and excessive presence of cadmium (Ali et al. 2013) or chromium (Ahmad et al. 2017). Our study demonstrated also a stimulatory effect of 5-ALA on transpiration intensity. On one hand, high transpiration intensity and a boost in stomatal conductance observed during drought stress may result in rapid plant dehydration, but on the other hand, they allow for maintaining gas exchange. Lowered photosynthesis rate during drought is mainly due to stomatal closure that limits availability of $\mathrm{CO}_{2}$ (Mansfield and Davies 1981).Other researchers reported the influence of 5-ALA on energy flow in thylakoid membranes (Ali et al. 2013; Liu et al. 2016) and quantum yield of PSII $\left(\mathrm{F}_{\mathrm{v}} / \mathrm{F}_{\mathrm{m}}\right)$ (Akram et al. 2012; Wang et al. 2018). Another positive effect of 5-ALA application included a boost in chlorophyll content under drought (Table 1, Table 2), which was probably due to the fact that 5-aminolevulinic acid serves as a precursor in chlorophyll biosynthesis (Akram and Ashraf 2013; Kosar et al. 2015; Ahmad et al. 2017; Akram et al. 2018).

We observed similar changes regarding photosynthesis, transpiration and stomatal conductance following the application of ZEN in plants exposed to soil drought (Table 3).These effects are concurrent with those reported by Kościelniak et al. (2009), who demonstrated a stimulatory effect of ZEN (pre-sowing seed soaking in the stimulator solution) on gas exchange in wheat at the stage of young ears visible and in soybean during rapid pod growth. However, they did not report an increase in the quantum yield of PSII (Fv/Fm). Kościelniak et al. (2009) proved that soaking wheat leaf discs for $48 \mathrm{~h}$ in the solutions of ZEN of various concentrations lowered the values of three parameters associated with light energy absorption (ABS/CS), amount of excitation energy trapped in PSII reaction centers $\left(\mathrm{TR}_{\mathrm{o}} /\right.$ $\mathrm{CS}_{\mathrm{m}}$ ), and the amount of energy used for electron transport $\left(\mathrm{ET}_{\mathrm{o}} / \mathrm{CS}_{\mathrm{m}}\right)$. Opposite effects for the same chlorophyll fluorescence parameters were reported for soybean (Kościelniak et al. 2011).

TRIA influence on maize condition was clearly visible at the seedling stage and included stimulation of water relations and elongation growth. Similar effect was observed in tomato, hyacinth bean and sweet basil (Khan et al. 2009; Naeem et al. 2009; Hashmi et al. 2011). Thakur et al. (1998) described the favorable effect of TRIA on leaf water content in olive plants exposed to soil drought. Reports on positive effects of TRIA on chlorophyll content and photochemical activity of PSII (Kumaravelu et al. 2000; Chen et al. 2002, 2003) were not clearly confirmed in our study, particularly regarding chlorophyll content (Tables 1, 2, Table 4).Similarly, to Eriksen et al. (1981), we showed no influence of TRIA on net photosynthesis in maize, even though this was previously reported for other plant species (Misra and Srivastava 1991; Naeem et al. 2009). Lack of TRIA impact on photosynthesis was unexpected, as the compound induces the activity of many genes involved in the process (Chen et al. 2002, 2003). Foliar application of L (+)-adenosine precursor in TRIA biosynthesis in maize, cucumber and tomato may induce changes in the level of $\mathrm{Ca}^{2+}, \mathrm{Mg}^{2+}$ and $\mathrm{K}^{+}$in the exudates obtained from the stumps (Ries et al. 1993). Plant response to TRIA depends on many factors, including species, developmental stage, stimulator dose, application manner, number of treatments, growth conditions and stress intensity (Eriksen et al. 1982).

The response to silicon preparation in plants exposed to soil drought differed based on developmental stages. Though silicon is still not considered an element essential for higher plants, its advantageous effects have been demonstrated for many species, especially under biotic or abiotic stress conditions (Ma et al. 2006; Liang et al. 2007; Etesami and Jeong 2018; Sirisuntornlak et al. 2019). The positive effects of silicon we observed in maize during drought stress (Table 1) were also reported in other cereals, i.e., sorghum and wheat (Gong et al. 2003; Hattori et al. 2005).Greater intensity of transpiration induced by this stress in maize (Table 3) corroborated similar results published by Hattori et al. (2005) for sorghum, and was accompanied by an increase in photosynthesis rate and stomatal conductance. Other authors speculated on a link between this effect and stimulation of root system development by $\mathrm{Si}$ and resulting enhancement of water uptake ability. In maize, silicon application during water stress did not alter root hydraulic conductance 
(Table 2). However, the element significantly influenced plant water status at earlier stages of three leaves (Table 1) and stem elongation (Table 2). This was manifested in higher RWC, and in the case of stem elongation stage also in higher osmotic potential (Table 2). The silicon preparation noticeably affected chlorophyll content at the stage of three leaves. In wheat leaves, $\mathrm{Si}$ application enhanced the contents of chlorophyll $a$, chlorophyll $b$, and carotenoids during cadmium stress (Hussain et al. 2015).

In summary, the impact of the investigated substances during drought stress depended on maize developmental stage. 5-ALA induced changes in photosynthesis by affecting chlorophyll level, gas exchange and photochemical activity of PSII.ZEN influence was highly similar to that of 5-ALA but apart from stimulating gas exchange and photochemical activity of PSII, it also induced stem elongation and limited plant dehydration. Beneficial effects of TRIA were the most perceptible at the stage of three leaves and involved leaf hydration and plant growth during drought. Silicon preparation triggered a response similar to TRIA at the stage of three leaves. Apart from improving water relations and plant growth, Si altered also chlorophyll levels. All the stimulators significantly affected transpiration intensity at the heading stage.

Author contribution statement AO carried out the experiment, data analysis and the preparation of manuscript. TH performed critical revision of the manuscript. MTG and TH participated in biochemical analysis. All authors read and approved the final manuscript.

Funding This study was funded by The F. Górski Institute of Plant Physiology Polish Academy of Sciences, Project for young researchers, no: 5457/E-189/M/2014 "Impact of selected biologically active substances on water management of maize".

\section{Declarations}

Conflict of interest The authors declare that they have no conflict of interest.

Open Access This article is licensed under a Creative Commons Attribution 4.0 International License, which permits use, sharing, adaptation, distribution and reproduction in any medium or format, as long as you give appropriate credit to the original author(s) and the source, provide a link to the Creative Commons licence, and indicate if changes were made. The images or other third party material in this article are included in the article's Creative Commons licence, unless indicated otherwise in a credit line to the material. If material is not included in the article's Creative Commons licence and your intended use is not permitted by statutory regulation or exceeds the permitted use, you will need to obtain permission directly from the copyright holder. To view a copy of this licence, visit http://creativecommons.org/licenses/by/4.0/.

\section{References}

Ahmad R, Ali S, Hannan F, Rizwan M, Iqbal M, Hassan Z, Akram NA, Maqbool S, Abbas F (2017) Promotive role of 5-aminolevulinic acid on chromium-induced morphological, photosynthetic, and oxidative changes in cauliflower (Brassica oleracea botrytis L.). Environ Sci Pollut Res 24:8814-8824

Akram NA, Ashraf M (2013) Regulation in plant stress tolerance by a potential plant growth regulator, 5-aminolevulinic acid. J Plant Growth Regul 32:663-679

Akram NA, Ashraf M, Al-Qurainy F (2012) Aminolevulinic acidinduced changes in some key physiological attributes and activities of antioxidant enzymes in sunflower (Helianthus annuus L.) plants under saline regimes. Sci Hortic 142:143-148

Akram NA, Iqbal M, Muhamma A, Ashraf M, Al-Qurainy F, Shafiq $S$ (2018) Aminolevulinic acid and nitric oxide regulate oxidative defense and secondary metabolisms in canola (Brassica napus L.) under drought stress. Protoplasma 255:163-174

Al-aghabary K, Zhu Z, Shi Q (2005) Influence of silicon supply on chlorophyll content, chlorophyll fluorescence, and antioxidative enzyme activities in tomato plants under salt stress. J Plant Nutr 27:2101-2115

Ali B, Wang B, Ali S, Ghani MA, Hayat MT, Yang C, Xu L, Zhou WJ (2013) 5-aminolevulinic acid ameliorates the growth, photosynthetic gas exchange capacity, and ultrastructural changes under cadmium stress in Brassica napus L. J Plant Growth Regul 32:604-614

Al-Khateeb SA (2006) Promotive effect of 5-aminolevulinic acid on growth, yield and gas exchange capacity of barley (Hordeum Vulgare L.) grown under different irrigation regimes. J King Saud Univ Agric Sci 18:103-111

Appenroth KJ, Stöckel J, Srivastava A, Strasser RJ (2001) Multiple effects of chromate on the photosynthetic apparatus of Spirodela polyrhiza as probed by OJIP chlorophyll a fluorescence measurement. Environ Pollut 115:49-64

Balakhnina T, Borkowska A (2013) Effects of silicon on plant resistance to environmental stresses: review. Int Agrophys 27:225-232

Balakhnina TI, Matichenkov VV, Wlodarczyk T, Borkowska A, Nosalewicz M, Fomina IR (2012) Effects of silicon on growth processes and adaptive potential of barley plants under optimal soil watering and flooding. Plant Growth Regul 67:35-43

Balestrasse KB, Tomaro ML, Batlle A, Noriega GO (2010) The role of 5-aminolevulinic acid in the response to cold stress in soybean plants. Phytochemistry 71:2038-2045

Barrs HD, Weatherley PE (1962) A re-examination of the relative turgidity techniques for estimating water deficits in leaves. Aust J Biol Sci 15:413-428

Biesaga-Kościelniak J (2001) Zearalenone as a new hypothetical regulator of plant growth and development. Polish Academy of Sciences, Krakow, Poland

Biesaga-Kościelniak J, Filek M (2010) Occurrence and physiology of zearalenone as a new plant hormone. In: Lichtfouse E (ed) Sustainable agriculture reviews 3: sociology, organic farming, climate changing and soil science. Springer, Dordrecht, pp 419-437

Biesaga-Kościelniak J, Marcińska I, Wędzony M, Kościelniak J (2003) Effect of zearalenone treatment in the production of wheat haploids via maize pollination system. Plant Cell Rep 21:1035-1039

Campos H, Cooper M, Habben JE, Edmeades GO, Schussler JR (2004) Improving drought tolerance in maize: a view from industry. Field Crops Res 90:19-34 
Chen X, Yuan H, Chen R, Zhu L, Du B, Weng Q, He G (2002) Isolation and characterization of triacontanol-regulated genes in rice (Oryza sativa L.): possible role of triacontanol as a plant growth stimulator. Plant Cell Physiol 43:869-876

Chen X, Yuan H, Chen R, Zhu L, He G (2003) Biochemical and photochemical changes in response to triacontanol in rice (Oryza sativa L.). Plant Growth Regul 40:249-256

Duan H, Li Y, Pei Y, Deng W, Luo M, Xiao Y-H, Luo K, Lu L, Smith W, Mcavoy R, Zhao D, Zheng X, Thammina C (2006) Auxin, Cytokinin and Abscisic acid: Biosynthetic and catabolic genes and their potential applications in ornamental crops. Journal of Crop Improv 18:347-364

Eriksen AB, Sellden G, Skagen D, Nilsen S (1981) Comparative analysis of the effect of triacontanol on photosynthesis, photorespiration and growth of tomato (C3-plant) and maize (C4-plant). Planta 152:44-49

Eriksen AB, Haugstad MK, Nilsen S (1982) Yield of tomato and maize in response to foliar and root applications of triacontanol. Plant Growth Regul 1:11-14

Etesami H, Jeong BR (2018) Silicon (Si): review and future prospects on the action mechanisms in alleviating biotic and abiotic stresses in plants. Ecotox Environ Safe 147:881-896

Filek M, Biesaga-Koscielniak J, Marcinska I, Cvikrová M, Macháčková I, Krekule J (2010) Contents of polyamines during vernalization in wheat and the effect of zearalenone. Biol Plantarum 54:483-487

Fu YF, Meng FJ (1994) Zearalenone in growth and development of winter wheat. Acta Agron Sin (Chinese, Engl Summ) 20:271-276

Fu YF, Han ZY, Zhao DG, Meng FJ (2000) Zearalenone and flower bud formation in thin-cell layers of Nicotiana tabacum L. Plant Growth Regul 30:271-274

Gadzinowska J, Ostrowska A, Hura K, Dziurka M, Pawłowska B, Hura $\mathrm{T}$ (2019) Physiological traits determining high adaptation potential of sweet briar (Rosa rubiginosa $\mathrm{L}$ ) at early stage ofgrowth to dry lands. Scientific Reports 9:19390

Ghahfarokhi MG, Mansurifar S, Taghizadeh-Mehrjardi R, Saeidi M, Jamshidi AM, Ghasemi E (2015) Effects of drought stress and rewatering on antioxidant systems and relative water content in different growth stages of maize (Zea mays L.) hybrids. Arch Agron Soil Sci 61(4):493-506

Gong HJ, Chen KM, Chen GC, Wang SM (2003) Effects of silicon on growth of wheat under drought. J Plant Nutr 26:1055-1063

Gunes A, Inal A, Bagci EG, Coban S, Sahin O (2007) Silicon increases boron tolerance and reduces oxidative damage of wheat grown in soil with excess boron. Biol Plant 51:571-574

Hajam MA, Hassan GI, Parray E, Wani MA, Shabir A, Khan IF, Wani AW, Bhat TA, Masoodi L (2018) Transforming fruit production by plant growth regulators. J Pharmacogn Phytochem 7:1613-1617

Hashmi N, Khan MMA, Naeem M, Idrees M, Aftab T, Moinuddin (2011) Ameliorative effect of triacontanol on the growth, photosynthetic pigments, enzyme activities and active constituents of essential oil of Ocimum basilicum L. Med Arom Plant Sci Biotechnol 5:20-24

Hattori T, Inanaga S, Araki H, An P, Morita S, Luxová M, Lux A (2005) Application of silicon enhanced drought tolerance in Sorghum bicolor. Physiol Plant 123:459-466

Hoagland DR (1948) Lectures on the inorganic nutrition of plants. Chronica Botanica Co, Waltham, Mass, USA

Hotta Y, Tanaka T, Takaoka H, Takeuchi Y, Konnai M (1997) Promotive effects of 5-aminolevulinic acid on the yield of several crops. Plant Growth Regul 22:109-114

Hura T, Hura K, Dziurka K, Ostrowska A, Bączek-Kwinta R, Grzesiak M (2012) An increase in the content of cell wall-bound phenolics correlates with the productivity of triticale under soil drought. J Plant Physiol 169:1728-1736
Hura K, Ostrowska A, Dziurka K, Hura T (2017) Photosynthetic apparatus activity in relation to high and low contents of cell wallbound phenolics in triticale under drought stress. Photosynthetica 55(4):698-704

Hussain I, Ashraf MA, Rasheed R, Asghar A, Sajid MA, Iqbal $M$ (2015) Exogenous application of silicon at the boot stage decreases accumulation of cadmium in wheat (Triticum aestivum L.) grains. Braz J Bot 38:223-234

Khan MMA, Bhardwaj G, Naeem M, Moinuddin F, Mohammad M, Singh M, Nasir S, Idrees M (2009) Response of tomato (Lycopersicon Esculentum Mill.) to application of potassium and triacontanol. Acta Hort (ISHS) 823:199-207

Korkmaz A, Korkmaz Y (2009) Promotion by 5-aminolevulenic acid of pepper seed germination and seedling emergence under lowtemperature stress. Sci Hortic 119:98-102

Korkmaz A, Korkmaz Y, Demirkiran AR (2010) Enhancing chilling stress tolerance of pepper seedlings by exogenous application of 5-aminolevulinic acid. Environ Exp Bot 67:495-501

Korndorfer GH, Lepsch I (2001) Effect of silicon on plant growth and crop yield. In: Datonoff L, Korndorfer G, Synder G (eds) Silicon in agriculture. Elsevier Science, New York, pp 133-147

Kosar F, Akrama NA, Ashraf M (2015) Exogenously applied 5-aminolevulinic acid modulates some key physiological characteristics and antioxidative defense system in spring wheat (Triticum aestivum L.) seedlings under water stress. S Afr J Bot 96:71-77

Kościelniak J, Biesaga-Kościelniak J, Janeczko A, Filek W, Kalaji HM (2009) Can the Giberella zeae toxin zearalenone affect the photosynthetic productivity and increase yield formation in spring wheat and soybean plants? Photosynthetica 47:586-594

Kościelniak J, Ostrowska A, Biesaga-Kościelniak J, Filek W, Janeczko A, Kalaji HM, Stalmach K (2011) The effect of zearalenone on PSII photochemical activity and growth in wheat and soybean under salt $(\mathrm{NaCl})$ stress. Acta Physiol Plant 33:2329-2338

Kumaravelu G, David LV, Ramanujam MP (2000) Triacontanolinduced changes in the growth, photosynthetic pigments, cell metabolites, flowering and yield of green gram. Biol Planta 43:287-290

Lazár D (1999) Chlorophyll a fluorescence induction. Biochim Biophys Acta 1412:1-28

Liang Y, Shen Q, Shen Z, Ma T (1996) Effects of silicon on salinity tolerance of two barley cultivars. J Plant Nutr 19:173-183

Liang Y, Sun W, Zhu YG, Christie P (2007) Mechanisms of siliconmediated alleviation of abiotic stresses in higher plants: a review. Environ Pollut 147:422-428

Liu M, Li J, Niu J, Wang R, Song J, Lv J, Zong X, Wang S (2016) Interaction of drought and 5-aminolevulinic acid on growth and drought resistance of Leymus chinensis seedlings. Acta Ecol Sin 36:180-188

Ma JF, Tamai K, Yamaji N, Mitani N, Konishi S, Katsuhara M, Ishiguro M, Murata Y, Yano M (2006) A silicon transporter in rice. Nature 440:688-691

Mansfield TA, Davies WJ (1981) Stomata and stomatal mechanisms. In: Paleg LG, Aspinall D (eds) The physiology and biochemistry of drought resistance in plants. Australia, Academic Press, Sydney, pp 315-346

Misra A, Srivastava NK (1991) Effects of the triacontanol formulations "Miraculan" on photosynthesis, growth, nutrient uptake, and essential oil yield of lemongrass (Cymbopogon flexuosus) Steud, Watts. Plant Growth Regul 10:57-63

Moussa HR (2006) Influence of exogenous application of silicon on physiological response of salt-stressed maize (Zea mays L.). Int J Agric Biol 8:293-297

Muthuchelian K, Bertamini M, Nedunchezhian N (2001) Triacontanol can protect Erythrina variegata from cadmium toxicity. J Plant Physiol 158:1487-1490 
Naeem M, Khan MMA, Moinuddin SMH (2009) Triacontanol stimulates nitrogen-fixation, enzyme activities, photosynthesis, crop productivity and quality of hyacinth bean (Lablab purpureus L.). Sci Hort 121:389-396

Naeem MS, Rasheed M, Liu D, Ming DF, Yoneyama K, Takeuchi Y, Zhou WJ (2011) 5-aminolevulinic acid ameliorates salinityinduced metabolic, water-related and biochemical changes in Brassica napus L. Acta Physiol Plant 33:517-528

Nishihara E, Kondo K, Parvez MM, Takahashi K, Watanabe K, Tanka K (2003) Role of 5-aminolevulinic acid (ALA) on active oxygenscavenging system in $\mathrm{NaCl}$-treated spinach (Spinacia oleracea). J Plant Physiol 160:1085-1091

Ostrowska A, Biesaga-Kościelniak J, Grzesiak MT, Hura T (2019) Physiological responses of spring wheat to 5-aminolevulinic acid under water stress applied at seedling stage. Cereal Res Commun 47:32-41

Perveen S, Iqbal M, Nawaz A, Parveen A, Mahmood S (2016) Induction of drought tolerance in Zea mays L. by foliar application of triacontanol. Pak J Bot 48:907-915

Rajasekaran LR, Blake TJ (1999) New plant growth regulators protect photosynthesis and enhance growth under drought of jack pine seedlings. J Plant Growth Regul 18:175-181

Rapacz M, Kościelniak J, Jurczyk B, Adamska A, Wójcik M (2010) Different patterns of physiological and molecular response to drought in seedlings of malt- and feed-type barleys (Hordeum vulgare). J Agron Crop Sci 196:9-19

Ries SK, Stutte CA (1985) Regulation of plant growth with triacontanol. Crit Rev Plant Sci 2:239-285

Ries SK, Wert V, Sweeley CC, Leavitt R (1977) Triacontanol: a new naturally occurring plant growth regulator. Science 195:1339-1341

Ries S, Savithiry S, Wert V, Widders I (1993) Rapid induction of ion pulses in tomato, cucumber, and maize plants following a foliar application of L (+)-adenosine. Plant Physiol 101:49-55

Shahbaz M, Noreen N, Perveen S (2013) Triacontanol modulates photosynthesis and osmoprotectants in canola (Brassica napus L.) under saline stress. J Plant Interact 8:350-359

Sirisuntornlak N, Ghafoori S, Datta A, Arirob W (2019) Seed priming and soil incorporation with silicon influence growth and yield of maize under water-deficit stress. Arch Agron Soil Sci 65(2):197-207

Srivastava A, Strasser RJ (1977) Constructive and destructive actions of light on the photosynthetic apparatus. J Sci Industrial Res 56:133-148

Stob M, Baldwin RS, Tuite JF, Andrews FN, Gillette KG (1962) Isolation of an anabolic uterotrophic compound from corn infected with Gibberella zeae. Nature 196:1318-1318
Strasser RJ, Srivastava A, Tsimilli-Michael M (2000) The fluorescence transient as a tool to characterize and screen photosynthetic samples. In: Yunus M, Pathre U, Mohanty P (eds) Probing photosynthesis: mechanism, regulation and adaptation. Taylor and Francis, London, pp 445-483

Sun YP, Zhang ZP, Wang LJ (2009) Promotion of 5-aminolevulinic acid treatment on leaf photosynthesis is related with increase of antioxidant enzyme activity in watermelon seedlings under shade condition. Photosynthetica 47:347-354

Szechyńska-Hebda M, Skrzypek E, Dąbrowska E, Biesaga-Kościelniak J, Filek M, Wędzony M (2007) The role of oxidative stress induced by growth regulators in the regeneration process of wheat. Acta Physiol Plant 329:327-337

Thakur A, Thakur PS, Singh RP (1998) Influence of paclobutrazol and triacontanol on growth and water relations in olive varieties under water stress. Indian J Plant Physiol 3:116-120

Tsonev S, Todorovska E, Avramova V, Kolev S, Abu-Mhadi N, Christov NK (2009) Genomics assisted improvement of drought tolerance in maize: QTL approaches. BiotechnolBiotec EQ 23:1410-1413

Tyree MT, Patino S, Bennink J, Alexander J (1995) Dynamic measurements of root hydraulic conductance using a high-pressure flowmeter in the laboratory and field. J Exp Bot 46:83-94

Von Wettstein D, Gough S, Kananagara CG (1995) Chlorophyll biosynthesis. Plant Cell 7:1039-1105

Wang Y, Wei S, Wang J, Su X, Suo B, Qin F, Zhao H (2018) Exogenous application of 5-aminolevulinic acid on wheat seedlings under drought stress enhances the transcription of $p s b A$ and $p s b D$ genes and improves photosynthesis. Braz J Bot 41:275-285

Wu Y, Liao W, Dawuda MM, Hu L, Yu J (2019) 5-Aminolevulinic acid (ALA) biosynthetic and metabolic pathways and its role in higher plants: a review. Plant Growth Regul 87:357-374

Xu F, Zhu J, Cheng S, Zhang W, Wang Y (2010) Effect of 5-aminolevulinic acid on photosynthesis, yield, nutrition and medicinal values of kudzu (Pueraria phaseoloides). Trop Grasslands $44: 260-265$

Publisher's Note Springer Nature remains neutral with regard to jurisdictional claims in published maps and institutional affiliations. 